\title{
Monika Dąbkowska*
}

Toruń

\section{Znaczenie teorii przywiązania i teorii systemowych w terapii osób wykorzystanych seksualnie}

Wykorzystanie seksualne dziecka uważa się za doświadczenie dlań niekorzystne - za czynnik ryzyka zaburzenia jego rozwoju psychoseksualnego. Badania dotyczące konsekwencji wykorzystania seksualnego potwierdzają tezę o negatywnym wpływie tego doświadczenia na rozwój człowieka. Wiedza o konsekwencjach wykorzystania seksualnego dziecka, mechanizmach ich powstawania, stanowi podstawę do projektowania profesjonalnych oddziaływań pomocowych przez pedagogów, psychologów i lekarzy.

Podczas planowania i prowadzenia procesu terapeutycznego kluczowe jednak jest uzyskanie zasobów i wsparcia w rodzinie dziecka wykorzystanego seksualnie. Niezbędna jest także edukacja rodziny obejmująca zapoznanie z ewentualnymi symptomami u dziecka, wskazującymi na doświadczanie przez nie wykorzystania, oraz ścieżki działań pomocowych. Budowanie tej wiedzy i kompetencji u członków rodziny jest działaniem, które jest niezbędne w procesie ujawniania wykorzystania seksualnego, ochrony dziecka i tworzenia wsparcia w procesie radzenia sobie $\mathrm{z}$ doświadczeniem wykorzystania. Biorąc pod uwagę właśnie znaczenie rodziny dla możliwości pomocy dziecku i budowy mechanizmów zaradczych, istotna jest perspektywa teorii przywiązania i koncepcje systemowe. Celem niniejszej pracy jest

* Dr Monika Dąbkowska jest adiunktem w Wydziale Nauk Pedagogicznych Uniwersytetu Mikołaja Kopernika w Toruniu, w Katedrze Tanatopedagogiki i Terapii. Adres: Wydział Nauk Pedagogicznych UMK, ul. Lwowska 1,87-100 Toruń; e-mail: mdabkow@umk.pl. 
ukazanie konieczności stosowania teorii przywiązania i teorii systemowych we wsparciu terapeutycznym osób wykorzystywanych seksualnie. Nie bez znaczenia jest także obecność poruszanego tematu w literaturze pedagogicznej, co ułatwi współpracę profesjonalistów zajmujących się dziećmi i młodzieżą z rodzicami oraz pomoże efektywniej budować programy pomocowe.

Mimo że problem wykorzystania seksualnego jest opisywany w literaturze naukowej, poradnikach dla rodziców i opiekunów, prowadzone są szkolenia i kampanie społeczne, to badania wskazują, że wiedza na temat reagowania w sytuacjach ujawnienia przemocy seksualnej jest niewystarczająca. Dotyczy to zarówno profesjonalistów działających na rzecz dzieci, jak i rodziców i opiekunów. Problem ten obserwowany jest zarówno w Polsce, jak i w innych krajach ${ }^{1}$.

\section{Istota i konsekwencje wykorzystania seksualnego}

W ciągu ostatnich kilku dekad wykorzystywanie seksualne dzieci dostrzegane jest jako istotny problem i rozpatrywane z perspektywy nauk pedagogicznych, psychologicznych i medycznych. Wykorzystywanie seksualne definiuje się najczęściej jako jakikolwiek kontakt seksualny z dzieckiem, który zapewniony jest osobie poprzez użycie siły, groźby lub podstępu, lub jakikolwiek kontakt seksualny z dzieckiem, które jest niezdolne do wyrażenia zgody ze względu na swój wiek i poziom rozwoju, niepełnosprawność lub różnicę siły².

Badania wskazują, że jeżeli kierujemy się szeroką definicją molestowania seksualnego jako, ,jakiegokolwiek zaangażowania seksualnego", rozpowszechnienie tego zjawiska wynosi $50 \%$, jeżeli natomiast bierzemy pod uwagę wąską definicję molestowania seksualnego, to znaczy „wymuszanie kontaktów genitalnych lub analnych", rozpowszechnienie sięga około 5\% populacji dzieci ${ }^{3}$. Chociaż dzieci obu płci zagrożone są doświadczeniem bycia wykorzystanym seksualnie, uważa się, że bardziej narażone są dziewczynki. Przywołać można na przykład badania retrospektywne, gdzie wśród

${ }^{1}$ Problem ten omawiany jest np. na stronach internetowych Fundacji Dajemy Dzieciom Siłę (dawniej Fundacja Dzieci Niczyje) - fdds.pl.

2 David Finkelhor, "Early and long-term effects of child sexual abuse: An update", Professional Psychology: Research and Practice 21 (1990): 325-330.

3 Jeffrey J. Haugaard, "The challenge of defining child sexual abuse", American Psychologist 55 (2000): 1036-1039. 
17337 dorosłych osób stwierdzono, iż 16\% mężczyzn i 25\% kobiet doświadczyło wykorzystania seksualnego, a konsekwencje psychologiczne i społeczne tego doświadczenia były równie dotkliwe dla obu $\mathrm{płci}^{4}$. Z polskich badań epidemiologicznych przeprowadzonych przez Zbigniewa Lwa-Starowicza wynika, że różnego typu kontaktów seksualnych przed 15. rokiem życia doświadczyło 19,6\% kobiet i 24,1\% mężczyzn. Jeśli rozszerzyć zakres zachowań zaliczanych do nadużyć seksualnych o formy bez użycia dotyku (ekspozycję genitaliów i czynności seksualnych dorosłych przed dzieckiem, kontakt z pornografią czy rozmowy o treści obscenicznej), wskaźnik ten sięga nawet $70 \%$ dzieci 5 .

Aktywność seksualna z udziałem osoby starszej bądź dorosłej przekracza możliwości efektywnego poradzenia sobie dziecka z tym doświadczeniem. Dziecko często nie rozumie istoty zachowania, w którym uczestniczy, nie potrafi rozpoznać jego znaczenia ani złożonych konsekwencji. Nie umie ocenić ani efektywnie regulować emocji oraz doznań, które mu wówczas towarzyszą. Z racji swych ograniczonych kompetencji społecznych dziecko uczestniczy w relacji na podporządkowanej pozycji, gdzie nie ma możliwości podjęcia decyzji o uczestnictwie w zachowaniach lub o ich formie. $\mathrm{Z}$ tego względu, że wykorzystanie seksualne przekracza tak wiele kompetencji dziecka, jest doświadczeniem niekorzystnym, obarczonym ryzykiem pojawienia się nieadekwatnych i ryzykownych dla dziecka mechanizmów zaradczych.

Poza powyższym dziecko uczestniczy w wykorzystaniu seksualnym jako obiekt umożliwiający osiągnięcie satysfakcji seksualnej przez drugą osobę. Tym samym jest sprowadzone do funkcji przedmiotu, gwaranta satysfakcji, z pominięciem lub eksploatacją jego przeżyć i uczestnictwa. Osoby, które dopuszczają się przemocy seksualnej wobec dzieci, są najczęściej im znane. Zdarza się także, że wykorzystanie seksualne następuje w rodzinie. Dodatkowo wzmaga to emocje związane z przekraczaniem norm moralnych, prawnych i społecznych. Niniejszy artykuł odnosi się do wsparcia terapeutycznego osób, które doświadczyły przemocy seksualnej - niezależnie od

${ }^{4}$ Shanta Dube, Robert Anda, Charles Whitfield, David Brown, Vincent Felitti, Maxia Dong, Wayne Giles, "Long-term consequences of childhood sexual abuse by gender of victim", American Journal of Preventative Medicine 28 (2005): 430-438.

5 Zbigniew Lew-Starowicz, „Seksuologia wieku dziecięcego i okresu dojrzewania”, w: Psychiatria wieku rozwojowego, red. Aniela Popielarska, Maria Popielarska (Warszawa: Wydawnictwo Lekarskie PZWL, 2000), 195-216. 
cech sprawcy i jego znajomości ofiary - to znaczy ze strony osób im obcych, znanych, a także członków rodziny.

Konsekwencje wykorzystania seksualnego pojawiać się mogą zarówno w okresie dzieciństwa, jak i później - w cyklu całego życia człowieka i są bardzo zróżnicowane. Wiele z nich to objawy niespecyficzne, pojawiające się w odpowiedzi na wykorzystanie seksualne, ale są powodowane również przez szereg różnych, innych czynników. Przegląd wyników badań nad konsekwencjami wykorzystania seksualnego u dzieci i młodzieży w wieku poniżej 18. roku życia pokazuje, że najczęściej pojawiającymi się symptomami u dzieci wykorzystanych są: seksualizacja zachowania, depresja, agresja, nadużywanie substancji psychoaktywnych, wycofanie oraz objawy zespołu stresu pourazowego. Nie są to jednak symptomy specyficzne, to znaczy ich pojawienie się nie pozwala jednoznacznie stwierdzić, że przyczyną jest wykorzystanie seksualne ${ }^{6}$.

Istnieje też znacząca grupa dzieci, u których doświadczenie wykorzystania seksualnego nie doprowadziło do rozwoju obserwowalnych negatywnych konsekwencji i symptomów klinicznych. Badania wskazują, że osoby takie stanowią $21-49 \%$ badanych grup. Wyjaśnia się to na trzy sposoby. Brak informacji o negatywnych skutkach wykorzystania seksualnego wynika z nieodpowiednio przygotowanych metod badania. Istnieje także możliwość, że osoby uczestniczyły w badaniu w nieodpowiednim czasie (kiedy jeszcze nie pojawiły się u nich negatywne konsekwencje lub też nie są już obserwowane). Możliwe jest też, że nadużycie seksualne nie pozostawiło w rzeczywistości negatywnych śladów w rozwoju dziecka lub zostały one zminimalizowane przez inne czynniki obecne w środowisku dziecka?

Doświadczenie wykorzystania seksualnego ma również znaczenie dla funkcjonowania emocjonalnego, poznawczego i społecznego dziecka, a także później - osoby dorosłej. Konsekwencje ujawniane w radzeniu sobie w codziennych sytuacjach są bardzo zróżnicowane wśród ofiar nadużyć seksualnych. Wahają się one od łagodnych emocjonalnych lub behawioralnych problemów, takich jak: niska samoocena, słabe wyniki w szkole; do poważnych zaburzeń i chorób psychicznych: depresji, zaburzeń zachowania

${ }^{6}$ Frank Putnam, "Ten-year research update review: Child sexual abuse", Journal of the American Academy of Child and Adolescent Psychiatry 42 (2003): 269-278.

${ }^{7}$ Kathleen A. Kendall-Tackett, Linda M. Williams, David Finkelhor, "Impact of sexual abuse on children: a review and synthesis of recent empirical studies", Psychological Bulletin 113 (1993): 164-180. 
$\mathrm{i}$ innych ${ }^{8}$. W funkcjonowaniu społecznym osoby pojawiają się często trudności z nawiązaniem i utrzymaniem relacji, zaufaniem do ludzi oraz wiarą we własne kompetencje interpersonalne 9 . W dorosłości osoby, które jako dzieci były wykorzystywane seksualnie, doświadczają również znacząco częściej problemów w związkach małżeńskich i relacjach seksualnych ${ }^{10}$.

Dla zrozumienia i terapii zaburzeń emocjonalnych i behawioralnych wynikających z doświadczenia nadużycia seksualnego sięgnąć można do teorii przywiązania. Pokazuje ona podstawową perspektywę rozwoju psychopatologii u dziecka, tłumaczy też rozregulowanie i trudności w kontaktach interpersonalnych. Holistyczne rozumienie zachowań i emocji wynikających z wykorzystania seksualnego musi obejmować relacje w rodzinie dziecka, ponieważ mogą być one specyficznymi, bardzo istotnymi czynnikami predykcyjnymi dla eskalacji doświadczanych konsekwencji. $Z$ drugiej strony relacje rodzinne mogą stanowić swoisty bufor chroniący dziecko przed ewentualnymi dalszymi konsekwencjami wykorzystania seksualnego lub znacznie je ograniczający. Natomiast branie pod uwagę ram teorii przywiązania w pracy terapeuty systemowego ułatwia rozumienie zarówno podwójnych interakcji oraz rodzinnego kontekstu, w którym wystąpiło wykorzystywanie seksualne, oraz wpływu tego doświadczenia na zdrowie i funkcjonowanie człowieka przez całe życie.

\section{Teoria przywiązania}

Od dawna dostrzegane jest znaczenie wczesnej więzi z opiekunem. Pierwsze lata życia dziecka są uznawane za fundamenty jego dalszego funkcjonowania, co podkreślają klasyczne badania nad zjawiskiem przywiązania $\mathrm{u}$ małych dzieci ${ }^{11}$. Zachowanie będące następstwem przywiązania przyjmuje wiele różnych wzorców w zależności od rodzaju przywiązania. Najbardziej istotną różnicę obserwuje się pomiędzy bezpiecznym i niedającym bezpieczeństwa przywiązaniem.

${ }^{8}$ Monika Zielona-Jenek, Aleksandra Chodecka, Jestem dziewczynka, jestem chłopcem. Jak wspomagać rozwój seksualny dziecka (Gdańsk: Gdańskie Wydawnictwo Psychologiczne, 2010), 236-242.

9 David DiLillo, "Interpersonal functioning among women reporting a history of childhood sexual abuse", Clinical Psychology Review 21 (2001): 553-576.

${ }^{10}$ Dube, Anda, Whitfield, Brown, Felitti, Dong, Giles, "Long-term”, 430-438.

${ }^{11}$ Za klasyczne prace osadzone w koncepcji więzi i przywiązania uznawane są badania J. Bowlby oraz M. Ainsworth. 
Według teorii przywiązania wczesna emocjonalna więź między opiekunem a dzieckiem ma zasadnicze znaczenie dla zdrowego rozwoju. Niemowlęta posiadają „,system przywiązania behawioralnego", który niezbędny jest do utrzymania bliskości opiekuna, co prowadzi u dziecka i dorosłego do spójnego poczucia bezpieczeństwa ${ }^{12}$. Pojęcie „bezpiecznej bazy” definiowane jest jako identyfikowanie przez dziecko opiekuna jako tej osoby, do której dziecko zwraca się w sytuacji, gdy jest mu potrzebna ochrona. Dzięki „bezpiecznej bazie” dziecko może utrzymywać swoisty balans pomiędzy zachowaniami eksplorującymi środowisko a bliskością osoby dorosłej. W tym znaczeniu więzi mogą być definiowane jako regulacja równowagi pomiędzy bezpieczeństwem a odkrywaniem i zabawą. Dzięki wielokrotnym, powtarzanym interakcjom niemowlęta uczą się, czego mogą oczekiwać i dostosowują swoje zachowanie do spodziewanych reakcji opiekuna.

Według teorii przywiązania doświadczenia poszczególnych osób z ich opiekunami są zinternalizowane poprzez wewnętrzne modele, które budują własne postrzeganie jednostki jako osoby godnej miłości i wsparcia, ale także ocenę wiarygodności i dostępności innych osób w późniejszym życiu. Te wewnętrzne modele pomagają dziecku interpretować i przewidywać doświadczenia w dorosłych związkach z innymi ludźmi. Dzieci, którym zapewniono troskliwą i odpowiedzialną opiekę, zazwyczaj postrzegają innych ludzi jako opiekuńczych i godnych zaufania, a siebie jako godnych miłości i opieki. Dzieci odrzucane, pomijane - odwrotnie - najczęściej traktują innych bez specjalnego zainteresowania i ufności, a siebie jako mało wartościowych i niegodnych miłości. W późniejszym dzieciństwie i dorosłości zachowanie w stosunku do innych i nawiązywanie nowych relacji przebiega zgodnie z wcześniejszymi doświadczeniami i oczekiwaniami ${ }^{13}$.

Prawie wszystkie dzieci tworzą więzi, ale różnią się one jakościowo. Opisano cztery style przywiązania dzieci z opiekunem w sposób dający lub niedający im poczucia bezpieczeństwa. Więzi tego niezapewniające dzielą się na trzy różne style przywiązania: unikający, oporny-ambiwalentny i zdezorganizowany-zdezorientowany ${ }^{14}$. Więzi niedające poczucia bezpie-

12 John Bowlby, "The making and breaking of affectional bonds", British Journal of Psychiatry 130 (1977): 201-210.

${ }^{13}$ Robert Goodman, Stephen Scott, „Więzi nie dające poczucia bezpieczeństwa”, w: Psychiatria dzieci i młodzieży, red. Jolanta Rabe-Jabłońska (Wrocław: Wydawnictwo Medyczne Urban \& Partner, 2000), 224-233.

${ }^{14}$ Barbara Józefik, Grzegorz Iniewicz, Koncepcja przywiąania. Od teorii do praktyki klinicznej (Kraków: Wydawnictwo Uniwersytetu Jagiellońskiego, 2008), 55-59. 
czeństwa mogą być odpowiedzią adaptacyjną na niesprzyjające okoliczności. Wśród dzieci, które doświadczyły przemocy lub zaniedbania, najczęściej opisywane są właśnie więzi pozabezpieczne. Natomiast bezpieczny styl przywiązania w dzieciństwie związany jest $\mathrm{z}$ większymi kompetencjami emocjonalnymi i społecznymi oraz efektywnym funkcjonowaniem w późniejszym dzieciństwie. Utworzony styl przywiązania ma znaczenie przez całe życie człowieka.

Młode osoby, które były wykorzystywane lub zaniedbywane, częściej prezentują niewłaściwe wzorce przywiązania. W okresie adolescencji osoba może nie komunikować objawów przywiązania, lecz jej potrzeba bezpiecznej bazy jest podobna jak u młodszych dzieci. Poczucie bezpieczeństwa to rodzaj „trampoliny”, pozwalającej na tworzenie własnej sieci wsparcia i relacji interpersonalnych. Młode osoby, u których wykształciło się bezpieczne przywiązanie, będą więc potrafiły przekształcić je w dojrzałą współzależność z innymi.

Właśnie przez określony styl przywiązania tłumaczyć można tak duże zmienności objawów psychologicznych i interpersonalnych u ofiar wykorzystania seksualnego - od ujawnianych zaburzeń i chorób psychicznych do zupełnego braku objawów psychopatologicznych ${ }^{15}$. Dostępne badania ujawniły także, że bezpieczne przywiązanie pomaga w radzeniu sobie po wykorzystaniu seksualnym - odczuwanie subiektywnie mniejszego cierpienia - aniżeli u osób z pozabezpiecznym stylem przywiązania ${ }^{16}$.

\section{Teoria systemów rodzinnych}

Koncepcje systemowe są częstym tematem dyskusji toczących się w obrębie pedagogiki i psychologii. Myślenie w kategoriach systemu można uznać za konieczne, ponieważ dzięki temu analizuje się całość zachowania człowieka w kategoriach wzajemnych powiązań, obiegu i zazębiania się informacji. Dla dziecka podstawowym systemem społecznym jest rodzina, obserwowany jest więc przede wszystkim wzorzec interakcji w rodzinie i często to on właśnie jest celem zmiany w terapii rodzinnej. W sytuacji wykorzystania seksualnego dziecka diagnozie i wynikającej z niej zmianie na-

${ }^{15}$ Pamela C. Alexander, "Application of attachment theory to the study of sexual abuse", Journal of Consulting \& Clinical Psychology 60 (1992): 185-195.

16 Deborah L. Shapiro, Alytia A. Levendosky, "Adolescent survivors of childhood sexual abuse", Child Abuse \& Neglect 23 (1999): 1175-1191. 
leży poddać nie tylko dziecko, lecz również interakcję i strukturę systemów, pod których wpływem ono pozostaje.

Koncepcje systemowe oparte są na założeniu, że wszystkie elementy układu są połączone ze sobą nawzajem, a prawdziwe zrozumienie rodziny nie jest możliwe, jeśli rozważa się te części oddzielnie. Terapeuta systemowy skupia się na interakcji zachodzącej pomiędzy częściami systemu, a cała rodzina jest jednostką analityczną ${ }^{17}$. Problemy rodziny rozważane są w perspektywie wzajemnych interakcji pomiędzy ludźmi. W tym wszystkie zachowania członków systemu oddziałują na środowisko, a w zamian środowisko wpływa na wszystkich członków systemu. Zatem każde zachowanie musi być brane pod uwagę także w kontekście dużego systemu. Ponadto, praktycy i teoretycy systemowi uważają, że wszystkie działania mają aspekty komunikacyjne $\mathrm{i}$ - w związku z tym - wydawane polecenia lub ujawniany przez rodzinę sposób komunikacji omawiane są podczas terapii, a nie treści tychże komunikatów. Zmiany w rodzinie mogą wystąpić na dwóch poziomach - poprzez pętlę sprzężenia zwrotnego w systemie. Pierwszy poziom odnosi się do małych zmian w zachowaniu między członkami rodziny, drugi poziom natomiast odnosi się do zmian w całym systemie. Dane zdarzenie nie prowadzi do jednego efektu; raczej zmiana u jednego z członków rodziny prowadzi do różnych reakcji u innych członków rodziny i szeregu reakcji wpływających na daną osobę, a także na innych członków rodziny. Zatem obserwacja procesów w rodzinie prowadzi do wniosku o istnieniu przyczynowości cyrkularnej (kolistej), a nie liniowej ${ }^{18}$.

Podstawową techniką podczas prowadzenia terapii systemowej jest zadawanie pytań cyrkularnych, tak aby można było stwierdzić istniejącą zależność między przekonaniami a zachowaniem. Stąd każde pytanie wywodzi się z odpowiedzi na poprzednie, a celem jest wykrycie znaczenia, jakie dla systemu mają poszczególne przekonania i odnalezienie ich wzajemnych powiązań. Podczas gdy linearny sposób zadawania pytań prowadzi stopniowo do coraz bardziej szczegółowego wglądu w stan umysłu i zachowanie badanego, pytania cyrkularne ujawniają związki między przekonaniami i relacje między poszczególnymi członkami rodziny. Poszukuje się zatem związków między doświadczeniami a systemem przekonań, zamiast z upo-

17 Irena Namysłowska, Terapia rodzin (Warszawa: Instytut Psychiatrii i Neurologii, 2000), 28-29.

${ }^{18}$ Herbert Goldenberg, Irene Goldenberg, Terapia rodzin (Kraków: Wydawnictwo Uniwersytetu Jagiellońskiego, 2006), 85-89. 
rem dążyć do wykrycia coraz to nowych szczegółów dotyczących samych doświadczeń ${ }^{19}$.

Ważną umiejętnością $\mathrm{w}$ nurcie systemowym podczas pracy $\mathrm{z}$ rodziną z dzieckiem po doświadczeniu wykorzystania seksualnego jest rysowanie genogramu. Pozwala członkom rodziny na szybkie umiejscowienie się w obrębie układu, rozpoznanie swoich ról, wpływów i znaczenia. Mogą ujawnić się wtedy wzorce interakcji między generacjami, a także przekonania rodzin o poszczególnych jej członkach (np. „On jest czarną owcą w rodzinie”, ,Jestem córeczką tatusia”, „Wszyscy mężczyźni w naszej rodzinie krzywdzą”) ${ }^{20}$.

Wykorzystywanie seksualne $\mathrm{w}$ rodzinie jest zdradą relacyjnych powiązań i ról rodzinnych. Niszczy umiejętność ofiary do zaufania i efektywnego wchodzenia $\mathrm{w}$ interakcje $\mathrm{z}$ innymi. Terapeuci systemowi pracują $\mathrm{z}$ ofiarami zarówno nadużyć seksualnych, jak i kazirodztwa od końca lat 60 . XX wieku. Na początku powszechne było przekonanie, że kazirodztwo jest ,sprawą rodzinną" i w związku z tym wszyscy członkowie rodziny powinni być obarczeni poczuciem odpowiedzialności za wykorzystanie seksualne. Takie myślenie miało na celu przypisanie winy dorosłym członkom rodziny, przy jednoczesnym zwolnieniu dzieci od stygmatyzujących obciążeń ${ }^{21}$. Niestety, model „sprawy rodzinnej” stopniowo przekształcił się w nieproporcjonalne obwinianie matek dzieci doświadczających przemocy seksualnej w rodzinie. W konsekwencji podczas interwencji skupiono uwagę na pomocy indywidualnej na rzecz ofiary. Współczesne trendy w terapii rodzinnej obejmują postrzeganie kazirodztwa nie tylko jako zdarzenia pojawiającego się w wyniku rozpadu normalnego życia rodzinnego, ale również łączą to zdarzenie $\mathrm{z}$ dynamiką poszczególnych elementów w systemie rodzinnym.

\section{Wsparcie terapeutyczne dla osób wykorzystanych seksualnie}

Aby pomóc ofiarom nadużyć seksualnych, terapeuci systemowi starają się zrozumieć konsekwencje wykorzystania seksualnego ujawniające się

19 Rüdiger Retzlaff, Speil-Räume. Lehrbuch der systemischen Therapie mit Kindern und Jugendlichen (Stuttgart: Klett-Cotta, 2008), 125-132.

${ }^{20}$ Barbara Tryjarska, „Terapia rodzin”, w: Psychoterapia. Praktyka, red. Lidia Grzesiuk (Warszawa: Wydawnictwo Psychologii i Kultury, 2006), 77-135.

${ }^{21}$ Sam Kirschner, Diana A. Kirschner, Richard L. Rappaport, The healing journey frontiers in couples and family therapy (New York: Brunner-Mazel, 1993). 
w ciągu całego życia, które dotykają także członków rodzin pokrzywdzonych. Dotychczasowe badania wskazują, że osoby wykorzystane seksualnie doświadczają emocjonalnych i interpersonalnych trudności głównie w trzech różnych obszarach: zdrady, bezsilności i stygmatyzacji ${ }^{22}$.

Poczucie zdrady może być opisane jako uznanie przez dzieci, że opiekun, od którego zależą, może im zaszkodzić i narusza on poprzez podejmowane zachowanie swoją rolę. W trakcie lub po zakończeniu wykorzystywania seksualnego dzieci zdają sobie sprawę, że zaufana osoba oszukała je poprzez kłamstwa lub nieprawdziwie formułowane normy moralne w celu zaspokojenia własnych potrzeb seksualnych. Bezsilność dziecka tworzy się w procesie nabywania przekonania, że jego wola i sprawstwo są ciągle podważane. Wzmacniana jest przez nieudane próby uwolnienia się od sprawcy i kwestionowanie wiarygodności zeznań dziecka. Stygmatyzacja polega na naznaczeniu dziecka jako ofiary, najczęściej poprzez obwinianie go za inicjatywę i przebieg kontaktu, uznanie za osobę gorszą. Dziecko rozpoczyna wtedy proces internalizacji negatywnych ocen innych osób na swój temat ${ }^{23}$.

Biorąc pod uwagę powyższe skutki wykorzystania seksualnego, ogromne znaczenie mają relacje $\mathrm{z}$ ważnymi dla dziecka dorosłymi, które tworzą nowe, konstruktywne i nieobarczone traumą doświadczenia. Wsparcie rodzinne i społeczne jest więc kluczowym czynnikiem w leczeniu ofiar nadużyć seksualnych i może stanowić swoisty bufor dla rozwoju konsekwencji nadużycia seksualnego, zwłaszcza gdy wpływa na zwiększenie poczucia własnej wartości. Badano między innymi zależność między wsparciem społecznym a ryzykiem doświadczenia ponownej napaści seksualnej. Osoby, które ponownie doświadczyły przemocy seksualnej, otrzymały wcześniej mniej wsparcia emocjonalnego i obarczane były w większym stopniu winą za zachowania sprawcy aniżeli osoby, które nie były więcej postawione w roli ofiary wykorzystania seksualnego. Podkreśla to znaczenie wsparcia społecznego w odzyskaniu zdrowia psychicznego i jego roli jako czynnika ochronnego przed kolejnymi zachowaniami mającymi na celu wykorzystanie seksualne osoby ${ }^{24}$.

${ }^{22}$ David Finkelhor, Angela Browne, "Impact of child sexual abuse: A review of the research", Psychological Bulletin 99 (1986): 66-77.

${ }^{23}$ Maria Beisert, „Wykorzystanie seksualne nieletnich - geneza, ofiary i sprawcy, następstwa", w: Podstawy seksuologii, red. Zbigniew Lew-Starowicz, Violetta Skrzypulec (Warszawa: Wydawnictwo Lekarskie PZWL, 2010), 238-248.

${ }^{24}$ Gillian E. Mason, Sarah Ullman, Susan Long, LaDonna Long, Laura Starzynski, "Social support and risk of sexual assault revictimization", Journal of Community Psychology 37 (2009): 58-72. 
Wykazano także, że wsparcie, jakie otrzymuje od rodziny wykorzystane dziecko, pośredniczy w znaczący sposób w ujawnianiu się konsekwencji w postaci zaburzeń emocjonalnych i behawioralnych. Kluczową rolę wsparcia rodziny dla leczenia ofiary wykorzystania seksualnego ilustruje zastosowanie w terapii teorii systemów. Cała rodzina postrzegana jest wtedy jako połączony system, który ma realny wpływ na wszystkie możliwości ratowania dziecka przed doświadczaniem szerokich i destruktywnych konsekwencji przemocy seksualnej.

Negatywne reakcje rodziny krzywdzonego dziecka mogą natomiast powodować eskalację poczucia zdrady, zwłaszcza gdy inni członkowie rodziny nie byli w stanie lub nie chcą chronić dzieci przed nadużyciami seksualnymi lub zmienili swój stosunek do dziecka po ujawnieniu wykorzystania w rodzinie. Innymi słowy, poczucie zdrady może być modyfikowane przez odpowiedź rodziny podejmowaną „wobec dziecka i niewłaściwych zdarzeń” 25 . To pokazuje, jak ważne jest zrozumienie wykorzystania seksualnego w systemie rodzinnym poprzez analizę jednostki i jak każdy członek rodziny może przyczynić się do ochrony zdrowia psychicznego ofiary. Jednocześnie brany pod uwagę styl przywiązania osoby ma znaczenie dla wykorzystania istniejącego bezpiecznego wzorca w celu odzyskania kompetencji emocjonalnych, behawioralnych i społecznych po traumatycznym przeżyciu wykorzystania seksualnego. Dostępne badania sugerują, że bezpieczny styl przywiązania i wynikające $\mathrm{z}$ tego późniejsze interakcje społeczne z rówieśnikami oparte na zaufaniu i więzi chronią w dużej mierze przed negatywnymi konsekwencjami nadużyć seksualnych ${ }^{26}$.

Styl przywiązania wywiera silny i bezpośredni wpływ na relacje w późniejszym życiu. Dorośli z pozabezpiecznymi stylami przywiązania mają postawy skutkujące zachowaniami niezgodnymi z normami społecznymi, problemy z samooceną i bardziej narażeni są na prawdopodobieństwo wystąpienia depresji ${ }^{27}$. Jednym z najważniejszych związków w dorosłym życiu człowieka najczęściej jest małżeństwo. Szczególnie trudne jest utrzymanie stabilnego związku przez osobę, która doświadczyła wykorzystania seksualnego. Małżeństwa te bowiem narażone są na konflikty i cierpienia z powodu

${ }^{25}$ Finkelhor, "Early", 325-330.

26 Jeffery E. Aspelmeier, Ann N. Elliott, Christopher H. Smith, "Childhood sexual abuse, attachment, and trauma symptoms in college females: The moderating role of attachment", Child Abuse \& Neglect 31 (2007): 549-566.

27 Joseph E. Roberts, Ian H. Gotlib, Jon D. Kassel, “Adult attachment security and symptoms of depression", Journal of Personality and Social Psychology 70 (1996): 310-320. 
historii partnera obarczonego maltretowaniem i zaniedbaniem, w połączeniu $\mathrm{z}$ nieprawidłowym modelem funkcjonowania relacji pomiędzy bliskimi osobami. Z jednej strony istotny jest więc styl przywiązania, gdyż bezpieczny daje potencjalną bazę do pracy dla terapeuty systemowego. $Z$ drugiej zaś strony w pracy z osobą, która doświadczyła przemocy seksualnej, i jej rodziną ważne jest skupienie się na wypracowaniu takich zachowań i modelów komunikacyjnych, które dadzą jak największą ochronę przed dalszymi możliwymi konsekwencjami wykorzystania seksualnego.

\section{Podsumowanie}

Terapię systemową traktować można nie tylko jako jedną z technik terapeutycznych, ale jako koncepcję funkcjonowania człowieka w relacji z innymi ludźmi i systemami go otaczającymi. Dużą zaletą znajomości terapii rodzin jest dostrzeganie wewnątrzrodzinnych wpływów na zachowania, co nie udaje się przy myśleniu , linearnym”. Terapia systemowa jest także bardzo często opisywana przez teoretyków i praktyków jako holistyczna koncepcja leczenia, która zakłada konieczność łączenia wielu metod terapeutycznych i współpracę profesjonalistów, szczególnie tych zajmujących się teorią przywiązania. Nurt holistyczny w terapii rodzin opiera się przede wszystkim na myśleniu systemowym o pacjencie prowadzącym do zrozumienia jego problemów behawioralnych i emocjonalnych w kontekście wielu systemów, w których funkcjonuje, zwłaszcza systemu rodzinnego. To właśnie myślenie, a nie techniki terapeutyczne stanowią istotę pracy, a zwłaszcza formowania programu terapeutycznego ${ }^{28}$.

Rola teorii przywiązania i koncepcji systemowych wydaje się szczególnie istotna w rozumieniu i wsparciu terapeutycznym dzieci, które doświadczyły wykorzystania seksualnego. Rodzina ma dla dziecka fundamentalne znaczenie. Z powodu wysokiej zależności dzieci i młodzieży od niej stanowi też podstawowy system odniesienia ${ }^{29}$. Inne systemy odgrywają znacznie mniejszą rolę. Kluczowe znaczenie ma więc poszukiwanie zasobów obec-

${ }^{28}$ Krzysztof Mudyń, „Zdarza się, że myślimy systemowo”, w: Ewolucja myślenia systemowego w terapii rodzin. Od metafory cybernetycznej do dialogu i narracji, red. Lech Górniak, Barbara Józefik (Kraków: Wydawnictwo Uniwersytetu Jagiellońskiego, 2003), 75-82; Namysłowska, Terapia, 188-199.

29 Ewa Paszkiewicz, „Rodzina jako system. Wpływ systemu rodzinnego na funkcjonowanie dziecka", w: Zaburzenia emocjonalne i behawioralne u dzieci, red. Tomasz Wolańczyk, Jadwiga Komender (Warszawa: Wydawnictwo Lekarskie PZWL, 2005), 39-42. 
nych w systemie rodzinnym dla wsparcia osoby, która doświadczyła nadużycia seksualnego. W piśmiennictwie panuje zgodny pogląd, że adekwatna, wzmacniająca reakcja rodziców - szczególnie w momencie ujawnienia przez dziecko informacji o nadużyciu - działa jak najlepszy bufor dla powstania traumy. I właśnie znaczenie rodziny w budowaniu sieci wsparcia dla osób, które doświadczyły wykorzystania seksualnego - od okresu dzieciństwa do dorosłości - powinno być nieustannie podkreślane w naukach pedagogicznych. Jest to istotne zarówno z perspektywy nabywania wiedzy i kompetencji u pedagogów - profesjonalistów, jak i z perspektywy praktyki pedagogicznej, w tym podejmowanej edukacji rodziców i opiekunów.

Zapewnienie wsparcia dziecku, które doświadczyło wykorzystania seksualnego, wymaga uwzględnienia pracy z jego opiekunami. Zapobiega to na przykład chybionym interwencjom z ich strony; pozwala uwspólnić cele pracy terapeutycznej z uwzględnieniem sytuacji dziecka, jego aktualnego wieku i poziomu rozwoju; wreszcie umożliwia budowanie kompetencji samych opiekunów ${ }^{30}$. Psycholog i pedagog podejmuje współpracę z opiekunem niebędącym sprawcą przemocy w celu zapewnienia dziecku wsparcia w środowisku rodzinnym i tym samym zwiększenia efektywności terapii. Relacja dziecka z niekrzywdzącym rodzicem bywa często zaburzona. Źródłem tych zaburzeń mogą być z jednej strony nieprawidłowe relacje z okresu wczesnego dzieciństwa - zaburzenia więzi i przywiązania lub, z drugiej strony, trudności (dotyczące całej rodziny) powstałe w wyniku doświadczenia molestowania dziecka przez osobę dorosłą. Współpraca z rodzicami dziecka molestowanego obejmuje zagadnienia tajemnicy, zaufania, szacunku, ale przede wszystkim ma na celu odtworzenie (bądź utworzenie) prawidłowych więzi emocjonalnych między dzieckiem a rodzicem. Szczególnie bowiem w sytuacji doświadczenia przez dziecko wykorzystania obecna jest u niego nasilona potrzeba bliskiego kontaktu i otrzymania pomocy.

W planowanie interwencji musi zaangażować się wielu różnych profesjonalistów i rodzina. Wsparcie dla dziecka, które doświadczyło wykorzystania seksualnego, najczęściej odbywa się poprzez pracę w formie terapii (osadzonej np. w nurcie systemowym). Natomiast praca z opiekunami obejmować może - poza uczestnictwem w terapii - formy edukacyjne, poradnictwo, czasem interwencję w kryzysie. Jakże istotna $\mathrm{z}$ tej perspektywy jest więc umożliwiająca decentrację współpraca profesjonalistów z zakresu pedagogiki i psychologii właśnie w tworzeniu tegoż wsparcia. Współpraca ta możliwa jest także dzięki obecności podjętego tematu w literaturze pe-

${ }^{30}$ Por. Zielona-Jenek, Chodecka, Jestem dziewczynka, 247-253. 
dagogicznej i psychologicznej. Realne wydaje się wtedy efektywne, systemowe wsparcie dla rodzin, w których dziecko było ofiarą wykorzystania seksualnego.

Połączenie specyficznej wiedzy na temat wykorzystania seksualnego oraz analizy przyczyn funkcjonowania jednostki z perspektywy teorii przywiązania oraz koncepcji systemowych warte jest uwzględnienia w procesach diagnostycznych i terapeutycznych - umożliwia diagnozę dzieci i młodzieży zbliżającą się bardziej do całościowej, a co za tym idzie - pozwala na skuteczne konstruowanie programów pomocy. Pomoc ta nie ogranicza się wówczas jedynie do psychoterapii, ale może dotyczyć szeroko pojętego środowiska i uwzględniać jego wpływy na funkcjonowanie dziecka. Analiza zjawiska wykorzystania seksualnego - przyczyn, różnic w reakcjach dzieci na to doświadczenie, możliwości pomocy - z perspektywy teorii przywiązania i koncepcji systemowych nie wyjaśnia wszystkich wątpliwości w pracy z dziećmi i młodzieżą obarczoną doświadczeniem molestowania. Jednak skierowanie uwagi specjalistów na znaczenie wczesnych doświadczeń w życiu dziecka oraz rolę systemu rodzinnego umożliwia podjęcie także oddziaływań profilaktycznych w stosunku do rodzin, ograniczających zjawisko wykorzystania seksualnego.

\section{The Importance of the Attachment and Systemic Theories in the Therapy of the Sexually Abused (Summary)}

The sexual abuse of a child is always unfavorable experience for him. It is a factor of risk for his psychosexual development. It is therefore crucial to look for the resources and possibilities to support the development of children and adolescents sexually abused in their families - especially when planning and conducting a diagnostic and therapeutic process. The purpose of this paper is to demonstrate the need for the use of attachment theory and systemic theories in the therapeutic support of sexually abused persons. The presence of the subject in pedagogical literature is also essential, which will facilitate the cooperation of professionals dealing with children and adolescents with parents and will help to build aid programs more effectively.

Keywords: sexual abuse; attachment theories; systemic theories; therapy; children and adolescents. 


\section{Znaczenie teorii przywiązania i teorii systemowych w terapii osób wykorzystanych seksualnie (Streszczenie)}

Wykorzystanie seksualne dziecka zawsze jest doświadczeniem dlań niekorzystnym. Stanowi czynnik ryzyka zaburzenia jego rozwoju psychoseksualnego. Kluczowe jest więc poszukiwanie zasobów i możliwości wsparcia rozwoju dzieci i młodzieży wykorzystanych seksualnie w ich rodzinach - szczególnie podczas planowania i prowadzenia procesu diagnostycznego oraz terapeutycznego. Celem niniejszej pracy jest ukazanie konieczności stosowania teorii przywiązania i teorii systemowych we wsparciu terapeutycznym osób wykorzystywanych seksualnie. Nie bez znaczenia jest także obecność poruszanego tematu w literaturze pedagogicznej, co ułatwi współpracę profesjonalistów zajmujących się dziećmi i młodzieżą z rodzicami oraz pomoże efektywniej budować programy pomocowe.

Słowa kluczowe: wykorzystanie seksualne; teorie przywiązania; teorie systemowe; terapia; dzieci i młodzież.

\section{Bibliografia}

Alexander, Pamela C. "Application of attachment theory to the study of sexual abuse". Journal of Consulting \& Clinical Psychology 60 (1992): 185-195.

Aspelmeier, Jeffery E., Ann N. Elliott, Christopher H. Smith. "Childhood sexual abuse, attachment, and trauma symptoms in college females: The moderating role of attachment". Child Abuse \& Neglect 31 (2007): 549-566.

Beisert, Maria. „Wykorzystanie seksualne nieletnich - geneza, ofiary i sprawcy, następstwa”. W: Podstawy seksuologii, red. Zbigniew Lew-Starowicz, Violetta Skrzypulec, 238-248. Warszawa: Wydawnictwo Lekarskie PZWL, 2010.

Bowlby, John. "The making and breaking of affectional bonds". British Journal of Psychiatry 130 (1977): 201-210.

DiLillo, David. "Interpersonal functioning among women reporting a history of childhood sexual abuse". Clinical Psychology Review 21 (2001): 553-576.

Dube, Shanta, Robert Anda, Charles Whitfield, David Brown, Vincent Felitti, Maxia Dong, Wayne Giles. "Long-term consequences of childhood sexual abuse by gender of victim". American Journal of Preventative Medicine 28 (2005): 430-438.

Finkelhor, David. "Early and long-term effects of child sexual abuse: An update". Professional Psychology: Research and Practice 21 (1990): 325-330. 
Finkelhor, David, Angela Browne. "Impact of child sexual abuse: A review of the research”. Psychological Bulletin 99 (1986): 66-77.

Goldenberg, Herbert, Irene Goldenberg. Terapia rodzin. Kraków: Wydawnictwo Uniwersytetu Jagiellońskiego, 2006.

Goodman, Robert, Stephen Scott. „Więzi nie dające poczucia bezpieczeństwa”. W: Psychiatria dzieci i młodzieży, red. Jolanta Rabe-Jabłońska, 224-233. Wrocław: Wydawnictwo Medyczne Urban \& Partner, 2000.

Haugaard, Jeffrey J. "The challenge of defining child sexual abuse". American Psychologist 55 (2000): 1036-1039.

Józefik, Barbara, Grzegorz Iniewicz. Koncepcja przywiąania. Od teorii do praktyki klinicznej. Kraków: Wydawnictwo Uniwersytetu Jagiellońskiego, 2008.

Kendall-Tackett, Kathleen A., Linda M. Williams, David Finkelhor. "Impact of sexual abuse on children: a review and synthesis of recent empirical studies". Psychological Bulletin 113 (1993): 164-180.

Kirschner, Sam, Diana A. Kirschner, Richard L. Rappaport. The healing journey frontiers in couples and family therapy. New York: Brunner-Mazel, 1993.

Lew-Starowicz, Zbigniew. „Seksuologia wieku dziecięcego i okresu dojrzewania”. W: Psychiatria wieku rozwojowego, red. Aniela Popielarska, Maria Popielarska, 195-216. Warszawa: Wydawnictwo Lekarskie PZWL, 2000.

Mason, Gillian E., Sarah Ullman, Susan Long, LaDonna Long, Laura Starzynski. "Social support and risk of sexual assault revictimization". Journal of Community Psychology 37 (2009): 58-72.

Mudyń, Krzysztof. „Zdarza się, że myślimy systemowo”. W: Ewolucja myślenia systemowego w terapii rodzin. Od metafory cybernetycznej do dialogu i narracji, red. Lech Górniak, Barbara Józefik, 75-82. Kraków: Wydawnictwo Uniwersytetu Jagiellońskiego, 2003.

Namysłowska, Irena. Terapia rodzin. Warszawa: Instytut Psychiatrii i Neurologii, 2000.

Paszkiewicz, Ewa. „Rodzina jako system. Wpływ systemu rodzinnego na funkcjonowanie dziecka”. W: Zaburzenia emocjonalne i behawioralne u dzieci, red. Tomasz Wolańczyk, Jadwiga Komender, 39-46. Warszawa: Wydawnictwo Lekarskie PZWL, 2005.

Putnam, Frank. "Ten-year research update review: Child sexual abuse". Journal of the American Academy of Child and Adolescent Psychiatry 42 (2003): 269-278.

Retzlaff, Rüdiger. Speil-Räume. Lehrbuch der systemischen Therapie mit Kindern und Jugendlichen. Stuttgart: Klett-Cotta, 2008.

Roberts, Joseph E., Ian H. Gotlib, Jon D. Kassel. "Adult attachment security and symptoms of depression". Journal of Personality and Social Psychology 70 (1996): 310-320. 
Shapiro, Deborah L., Alytia A. Levendosky. "Adolescent survivors of childhood sexual abuse". Child Abuse \& Neglect 23 (1999): 1175-1191.

Tryjarska, Barbara. „Terapia rodzin”. W: Psychoterapia. Praktyka, red. Lidia Grzesiuk, 77-135. Warszawa: Wydawnictwo Psychologii i Kultury, 2006.

Zielona-Jenek, Monika, Aleksandra Chodecka. Jestem dziewczynka, jestem chłopcem. Jak wspomagać rozwój seksualny dziecka. Gdańsk: Gdańskie Wydawnictwo Psychologiczne, 2010. 
